\title{
Determination of Organic Compounds in Landfill Leachates Treated by Coagulation-Flocculation and Fenton-Adsorption
}

\author{
Nesrine Turki ${ }^{1}$, Dalel Belhaj ${ }^{2 *}$, Ikram Jaabiri ${ }^{3}$, Habib Ayadi ${ }^{4}$, \\ Monem Kallel ${ }^{5}$, Jalel Bouzid ${ }^{6}$ \\ ${ }^{1-2-3-5-6}$ University of Sfax-Tunisia, ENIS. Laboratory of Water-Energy-Environment. Street Soukra Km 3.5. BP \\ 1173 CP 3038.
}

\begin{abstract}
The objective of this study was to identify the organic compounds removed from the leachates when treated with coagulation-flocculation and Fenton-Adsorption by gas chromatography coupled to mass spectrometry $(G C-M S)$ in order to identify toxic compounds that could be harmful for the environment or human health.

Physico-chemical characterization of the raw leachates (RL) was carried out before and after the aforementioned combined treatment process. The effluent from each stage of this process was characterized: $p H$, Biological Oxygen Demand $\left(B O D_{5}\right)$, Chemical Oxygen Demand (COD), turbidity and Total Suspended Solids (TSS). The organic compounds were determined by GC-MS.

The removal of $C O D$ and $B O D_{5}$ reached over $91 \%$ in compliance with the Tunisian Standards (NT 106.002-1989), which establishes the maximum permissible limits for contaminants present in wastewater discharges to urbanized streams. The chromatographic analysis from the Adsorption effluent proved that this treatment removed more than $99 \%$ of the organic compounds present in the initial sample. The phytotoxicity test showed that combined treatment process allowed a significant toxicity removed $(92.2 \%)$. The mono (2ethylhexyl) ester 1,2-benzenedicarboxylic acid persisted, although it is not considered as toxic compound by the NT 106.002-1989) Therefore, the treated effluent can be safely disposed of into the urbanized streams.

Keywords: Adsorption; Coagulation-Flocculation; Fenton; Landfill leachates; Organic compounds; phytoxicity
\end{abstract}

\section{Introduction}

In Tunisia, 1700 tones of domestic garbage are collected daily [1]. Landfilling is a fundamental step in any waste management strategy. Landfill leachates have been identified as potential sources of ground and surface waters contamination, as they may percolate through soils and subsoils, causing extensive pollution and toxicity. It generate a large amount of refractory organic compounds such as phenols [2], polycyclic aromatic hydrocarbons [3] alkanes, ketones, esters, alcohols [4] and Phthalates [5]; therefore, their treatment is complicated and generally requires the application of various process [6]. The ability of anaerobic and aerobic biological processes to reduce the organic load of landfill leachates has been studied, and these processes are quite effective when applied to acetogenic leachates containing mainly volatile fatty acids. However, these processes are less efficient for the treatment of methanogenic leachates [7]. Many physico-chemical techniques have been proposed for the treatment of wastewaters that contain high concentrations of refractory organic matter. These techniques include ozonisation, ultrasound treatment, coagulation-flocculation, Fenton and adsorption processes; among these, the Fenton processes are very effective $[8,9,10]$. These treatment makes possible the transformation of recalcitrant compounds into biodegradable products. The Fenton process is an advanced Oxidation process (AOP) that is effective, simple and inexpensive and is based on the use of ferrous salts that activate $\mathrm{H}_{2} \mathrm{O}_{2}$ from highly oxidizing $\mathrm{OH}$ radicals. This system promotes the formation of the highly reactive hydroxyl radicals, able to oxidize a wide range of compounds [11]. High $\mathrm{H}_{2} \mathrm{O}_{2}$ doses lead to a higher amount of $\mathrm{HO}^{\bullet}$, however, when in excess, hydrogen peroxide reveals a radical scavenging capacity, decreasing the treatment efficiency once then hydroperoxyl radicals $\left(\mathrm{HO}_{2}{ }^{\circ}\right)$. Generally, the Fenton reactant doses are determined as a function of the leachate organic content $\left(\left[\mathrm{Fe}^{2+}\right] /\left[\mathrm{H}_{2} \mathrm{O}_{2}\right]\right.$ and $[\mathrm{COD}] /\left[\mathrm{H}_{2} \mathrm{O}_{2}\right]$, the oxidation time and the $\mathrm{pH}[12]$.

The Fenton process generates high volumes of light sludge which is difficult to remove by decantation. The filtration process has been tested successfully, microfiltration reached removal $75 \%$ in COD and $95 \%$ in color [13].

Another physicochemical process that has been used to treat leachates is adsorption [14,15]. It is a process by which a substance is transferred from the liquid phase to the surface of a solid and becomes bound by physical and/or chemical interactions. Because of its large surface area, microporous structure and surface reactivity, powder activated carbon adsorption is one of the most attractive methods for the removal of recalcitrant compounds from leachates [16]. The adsorption of pollutants provides great reduction in COD levels, whatever the initial organic matter concentration [17]. On the other hand, the adsorption process can 
reduce the residual metal ions and ammonia nitrogen. However, the main drawbacks are the need for frequent regeneration and high consumption of adsorbent.

The Mediterranean countries are characterized by a severe water imbalance, mainly in the summer months [18]. Moreover, increasing agricultural reuse of treated effluent serves goals such as promoting sustainable agriculture, preserving scare water resources, and maintaining environmental quality; therefore, the aim of this study was to identify organic compounds removed by applying the combination of coagulationfloculation and Fenton-Adsorption process to the leachates from the landfill of the city of Bizerte, Tunisia, using gaz chromatography coupled to mass spectrometry (GC-MS) in order to assess the potential risk of pollution that raw and treated leachates pose.

\subsection{Site description}

The site used for this study was the sanitary landfill site of Bizerte, North Eastern Tunisia $\left(37^{\circ} 16^{\prime} \mathrm{N}\right.$; $\left.9^{\circ} 52^{\prime} \mathrm{E}\right)$ (Fig.1).

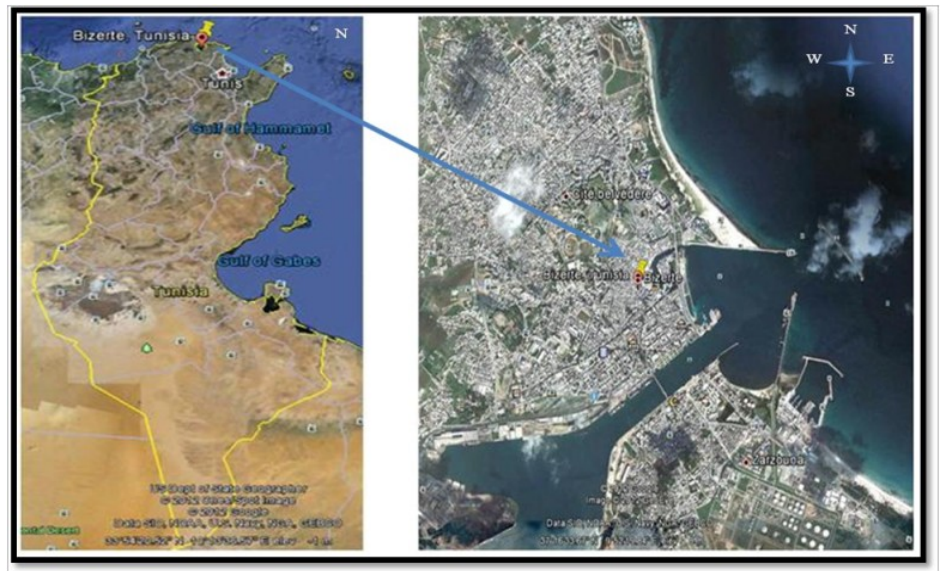

Figure 1. Localization site

A leachate management program has been applied, involving the collection of leachates through a drainage network and the continuous re-circulation through the deposited landfill. At the lowest point of landfill, leachates exits to the surface, forming an evaporation pond. About $60 \mathrm{~m}^{3} \mathrm{day}^{-1}$ of leachates are transferred to the main wastewater treatment plant for further treatment.

\subsection{Sampling campaigns}

Four samplings were carried out in the evaporation pond of the landfill between July and October 2012. In each sampling, $40 \mathrm{~L}$ of leachates were collected in four different points of the evaporation pond. Samples were transported to the laboratory, stored at $4{ }^{\circ} \mathrm{C}$ and analyzed within 2 days.

Physico-chemical characteristics of leachate samples were validated according to French standard NF XPT 90-210 [19]. Biochemical oxygen demand $\left(\mathrm{BOD}_{5}\right)$ was determined by the manometric method with a respirometer (BSB-Controlled Model OxiTop (WTW)) and the chemical oxygen demand (COD) was estimated using the method described by Knechtel [20]. Total nitrogen contents (TN) were measured by the Kjeldhal method using an automated apparatus (Buchi, Switzerland). Phosphorus was determined colorimetrically at 430 $\mathrm{nm}$ using a Shimadzu U 1000 spectrophotometer [21]. The phosphorus content (TP) was measured calorimetrically by atomic absorption (ICE, 3000 model). The $\mathrm{pH}$ was measured using $\mathrm{pH}$ meter (INOLAB WTW 720). Electrical conductivity (CE) was determined with an electronic conductivity meter (TACUSSEL, $\mathrm{CD} 6 \mathrm{NG}$ ) equipped with an immersion measurement probe (cell constant $\mathrm{Ks} \mathrm{L}^{-1}=1 \mathrm{~cm}$ ). The total suspending solid content (TSS) was assessed by drying at $105^{\circ} \mathrm{C}$ for $12 \mathrm{~h}$ [22].

The removal efficiency (RE) was determined as the percentage of decrease in influent with respect to effluent for each parameter measured.

\subsection{Treatment process}

\subsubsection{Application of the Coagulation-flocculation process}

Coagulation-flocculation experiments were carried out in a conventional jar-test apparatus, equipped with 6 beakers of $1000 \mathrm{~mL}$ volume at room temperature (around $18{ }^{\circ} \mathrm{C}$ ). Leachate samples were removed from the refrigerator and were remained for about $2 \mathrm{~h}$ under ambient temperature. Then, sample bottles were thoroughly shaken, for re-suspension of possibly settling solids and the appropriate volume of sample was transferred to the corresponding jar test beakers. The $\mathrm{pH}$ of raw leachates (RL) was adjusted to the level of 5.5 by the addition of appropriate amounts of $\mathrm{H}_{2} \mathrm{SO}_{4}$ and the coagulation-flocculation was applied with $0.6 \mathrm{~g} \mathrm{~L}^{-1}$ of 
$\mathrm{FeCl}_{3} \cdot 6 \mathrm{H}_{2} \mathrm{O}$. The experimental process consisted of three subsequent stages: the initial rapid mixing stage took place for $6 \mathrm{~min}$ at $200 \mathrm{rpm}$, followed by a slow stage for $60 \mathrm{~min}$ at $60 \mathrm{rpm}$. Stirring was then discontinued and the sludge was left to settle for $2 \mathrm{~h}$. After the settling period, the supernatant was withdrawn from the beakers by using a plastic syringe $(50 \mathrm{~mL})$ from a point located about $2 \mathrm{~cm}$ below the top of liquid level at the beaker.

\subsubsection{Application of the Fenton process}

Fenton experiments were conducted in a $1000 \mathrm{~mL}$ glass beaker. $400 \mathrm{~mL}$ of leachates treated by coagulation-flocculation process ( $\mathrm{TL}_{\mathrm{CF}}$ ) was acidified to $\mathrm{pH} 3$ using $\mathrm{H}_{2} \mathrm{SO}_{4}$ and introduced into the reactors and agitated in an orbital shaker at $10 \mathrm{rpm}$. Fenton oxidation was applied by addition of Fenton reagents $\left(\mathrm{FeSO}_{4} .7\right.$ $\left.\mathrm{H}_{2} \mathrm{O}\right)$ and Hydrogen peroxide $\left(\mathrm{H}_{2} \mathrm{O}_{2}(30 \% \mathrm{~W} / \mathrm{W})\right)$ with dose of $1200 \mathrm{mg} \mathrm{L}^{-1}$ and $2.4 \mathrm{~g} \mathrm{~L}^{-1}$, respectively. The molar ratio of $\mathrm{H}_{2} \mathrm{O}_{2}$ to $\mathrm{Fe}^{2+}$ was 2 . The leachate was then filtered using a filter press (ULVAC, SINKUKIKO; G20D), using a filter (Schleicher and Schuell of $25 \mu \mathrm{m}$ pores).

\subsubsection{Application of Adsorption process}

Adsorption experiments were performed in erlenmeyer flasks where $200 \mathrm{~mL}$ of treated leachates by Fenton process $\left(\mathrm{TL}_{\mathrm{F}}\right.$ ) was mixed with $20 \mathrm{~g} \mathrm{~L}^{-1}$ of powdered activated carbon (Kanto chemical Co. INK. Cica reagent) and then shaken for a period of $3 \mathrm{~h}$ at $150 \mathrm{rpm}$. The temperature of adsorption was $20 \pm 1{ }^{\circ} \mathrm{C}$. The samples were centrifugated at $6000 \mathrm{rpm}$ for $20 \mathrm{~min}$.

\subsection{Chromatographic analysis}

Samples of the $\mathrm{RL}, \mathrm{TL}_{\mathrm{CF}}, \mathrm{TL}_{\mathrm{F}}$ and the effluent from the adsorption $\left(\mathrm{TL}_{\mathrm{A}}\right)$ were collected and analyzed by GC-MS in order to identify organic compounds.

The sample processing and analysis is a modification method of the previously described method of Sang et al. [23]. Briefly, the pH of $500 \mathrm{~mL}$ of the collected samples was adjusted to 12 using $\mathrm{NaOH} 10 \mathrm{~N}$ and three liquid-liquid extractions (LLE) were made using volumes of $50 \mathrm{~mL}$ of chromatographic grade $\mathrm{CH}_{2} \mathrm{Cl}_{2}$. The organic extract was separated in a flask. Then the $\mathrm{pH}$ of the aqueous fraction from the extraction was adjusted to 2 with $\mathrm{H}_{2} \mathrm{SO}_{4} 10 \mathrm{~N}$. The LLE was repeated with three volumes of $50 \mathrm{~mL}$ of $\mathrm{CH}_{2} \mathrm{Cl}_{2}$. The separated acidic and alkaline organic phases were mixed and condensed to $5 \mathrm{~mL}$ with a Buchi rotoevaporator in a water bath at $42{ }^{\circ} \mathrm{C}$ vial for GC-MS analysis.

The GC-MS analyses were carried out with gas chromatography (GC, Hewlett-Packard 6890 Series, Agilent Technology) equipped with a mass spectrometer (MS, Hewlett-Packard 5973 Mass Selective Detector, Agilent Technology). A HP-5MS fused silica capillary column $(60 \mathrm{~m} \times 0.25 \mathrm{~mm}$ i.d., $0.25-\mu \mathrm{m}$ film thickness, Agilent Technology) was used. The GC oven temperature was programmed as follows: $100{ }^{\circ} \mathrm{C}$ hold for $2 \mathrm{~min}$, raised at $5{ }^{\circ} \mathrm{C} \mathrm{min}{ }^{-1}$ to $290{ }^{\circ} \mathrm{C}$ (held for $20 \mathrm{~min}$ ). Helium was the carrier gas at a flow rate of $1.07 \mathrm{~mL} \mathrm{~min}^{-1}$. The injection was set on a split less mode at $250^{\circ} \mathrm{C}$. The volume injected was $1.0 \mu \mathrm{L}$, the solvent delay was 10.00 min and total run time was $60 \mathrm{~min}$. Detection was conducted by a mass selective detector with electron impact ionization at $70 \mathrm{eV}$, in selected ion monitoring mode. MS transfer line temperature was at $280{ }^{\circ} \mathrm{C}$. The MS was operated in full scan in electron ionization mode with an electron multiplier voltage of $2200 \mathrm{~V}$. The mass scanning ranged from $\mathrm{m} / \mathrm{z} 50$ to 550 . Mass spectra were compared to the reference compounds in Wiley $275 \mathrm{~L}$ mass spectral library.

The semi-quantification and the removal of persistent compounds in each stage of the process were performed by comparing the corrected areas of specific peaks to the peak area.

\subsection{Toxicity test}

The phytotoxicity was assessed on seed germination of tomato (Lycopersicon. esculentum). According to a modified Zucconi test [24] by measuring seed germination. Prior to test, the seeds were surface-sterilized in $3 \%(\mathrm{v} / \mathrm{v})$ hydrogen peroxides for $15 \mathrm{~min}$ and then rinsed with deionized water. Ten undamaged seeds with identical size were placed uniformly in $90 \mathrm{~cm}$ petri dishes, in a filter. Five dilutions of the sample and one control were prepared with three replicates. Each dish contained $5 \mathrm{ml}$ sample dilution or $5 \mathrm{ml}$ of distilled water (control). Three replicates were carried out for each sample, including the control. Dishes were then covered and incubated in the dark at $20 \pm 2{ }^{\circ} \mathrm{C}$ for 5 days. A germination index $(G I)$ was calculated by counting the number of germinated seeds and the average root length observed in each sample compared to control seeds. Seeds were considered to have germinated when the radical penetrates the seed coat [25].

The median effective concentration ( $\mathrm{EC}_{50}$ ) was calculated from the dose relationship between GI and leachates concentration by the brain cousens model [26]. The evaluation of toxicity was performed by transforming the $\mathrm{EC}_{50}$ values into toxic units according to the following formula: $\mathrm{TU}=100 / \mathrm{EC}_{50}$. 


\section{Result and Discussion}

\subsection{Physico-chemical characteristics of leachates}

The RL had a high COD content of $16.200 \mathrm{~g} \mathrm{~L}^{-1}$ and low biodegradability index (BI) expressed as the ratio of $\mathrm{BOD}_{5 \mathrm{~T}}$ and $\mathrm{COD}_{\mathrm{T}}($ Table 1), making it unsuitable for treatment by biological process. Ramirez et al. [27] reported similar values to those obtained in this study. Additionally, the amount of ammonia was approximately $2.35 \mathrm{~g} \mathrm{NH}^{+}$; compared with this value, $\mathrm{P}$ contents can be considered negligible (Table 1 ). The $\mathrm{pH}$ was 8.11 and only small concentrations of metal ions were observed. The $\mathrm{pH}$ value, the low biodegradability and the high ammonia concentration detected in the samples are typical of methanogenic leachates.

Table 1. Physico-chemical characterization of leachate sample and legal limits for discharge throughout the local sewage

\begin{tabular}{|c|c|c|}
\hline Parameters & Raw leachate & ${ }^{\mathrm{a}} \mathrm{LLD}$ \\
\hline $\mathrm{pH}$ & 8.11 & $6.5-9$ \\
\hline Turbidity (NTU) & 422 & nd \\
\hline Total COD $\left(\mathrm{mg} \mathrm{O}_{2} \mathrm{~L}^{-1}\right)$ & 16200 & 1000 \\
\hline Soluble COD $\left(\mathrm{mgO}_{2} \mathrm{~L}^{-1}\right)$ & 15900 & - \\
\hline $\mathrm{BOD}_{5}\left(\mathrm{mgO}_{2} \mathrm{~L}^{-1}\right)$ & 2430 & 400 \\
\hline $\mathrm{TKN}\left(\mathrm{mg} \mathrm{L}^{-1}\right)$ & 2350 & 100 \\
\hline $\mathrm{N}-\mathrm{NH}^{4+}\left(\mathrm{mg} \mathrm{L}^{-1}\right)$ & 2120 & 100 \\
\hline Total P $\left(\mathrm{mg} \mathrm{L}^{-1}\right)$ & 13.64 & 10 \\
\hline $\mathrm{TSS}\left(\mathrm{mg} \mathrm{L}^{-1}\right.$ & 491 & - \\
\hline $\operatorname{TDS}\left(\mathrm{mg} \mathrm{L}^{-1}\right)$ & 1953 & - \\
\hline $\mathrm{DBO}_{5} / \mathrm{DCO}$ & 0.15 & - \\
\hline Absorbance (at $460 \mathrm{~nm}$ ) & 1.192 & ${ }^{b}$ nd \\
\hline $\mathrm{Mn}\left(\mathrm{mg} \mathrm{L}^{-1}\right)$ & 0.15 & 1 \\
\hline $\mathrm{Cu}\left(\mathrm{mg} \mathrm{L}^{-1}\right)$ & 0.0871 & 1 \\
\hline $\mathrm{Zn}\left(\mathrm{mg} \mathrm{L}^{-1}\right)$ & 0.00251 & 5 \\
\hline $\mathrm{Cd}\left(\mathrm{mg} \mathrm{L}^{-1}\right)$ & ${ }^{b}$ nd & 0.1 \\
\hline $\mathrm{Fe}\left(\mathrm{mg} \mathrm{L}^{-1}\right)$ & 6.87 & 5 \\
\hline $\mathrm{Al}\left(\mathrm{mg} \mathrm{L}^{-1}\right)$ & 1.73 & 10 \\
\hline $\mathrm{Cr}\left(\mathrm{mg} \mathrm{L}^{-1}\right)$ & 1.64 & 2 \\
\hline $\mathrm{Pb}\left(\mathrm{mg} \mathrm{L}^{-1}\right)$ & n. $\mathrm{d}$ & 1 \\
\hline
\end{tabular}

${ }^{a}$ LLD: legal limits for discharge throughout the local sewage; ${ }^{b}$ nd: not detected

The effluent from the combined treatment process reached over $98 \%$ removal for total $\mathrm{COD}\left(\mathrm{COD}_{\mathrm{T}}\right)$ and soluble $\mathrm{COD}\left(\mathrm{COD}_{\mathrm{S}}\right)$ and $90 \%$ for $\mathrm{BOD}_{5}$ (Table 2$)$. The value of $\mathrm{COD}_{\mathrm{S}} / \mathrm{COD}_{\mathrm{T}}$ for raw leachates was close to 1 , indicating that most of the organic matter was dissolved [28]. The effluent from the adsorption process reached $\mathrm{COD}$ and $\mathrm{BOD}_{5}$ values lower than the maximum allowed by the existing legislative guidelines for the discharge of treated wastewaters in the urbanized streams (NT 106.002 1989) (1000 and $400 \mathrm{mg} \mathrm{L}^{-1}$, respectively).

Table 2. Physico-chemical characterization of treated leachate and legal limits for discharge throughout the local sewage

\begin{tabular}{|c|c|c|c|c|}
\hline Parameters & ${ }^{\mathrm{a}} \mathrm{TL}_{\mathrm{CF}}$ & ${ }^{\mathrm{b}} \mathrm{TL}_{\mathrm{F}}$ & ${ }^{\mathrm{c}} \mathrm{TL}_{\mathrm{A}}$ & LLD \\
\hline $\mathrm{pH}$ & 5.5 & 3 & 8.6 & $6,5<\mathrm{PH}<9$ \\
\hline Turbidity (NTU) & 42.2 & 27 & 0.61 & \\
\hline Total COD $\left(\mathrm{mgO}_{2} \mathrm{~L}^{-1}\right)$ & 9102 & 2912.64 & 398 & 1000 \\
\hline Soluble $\mathrm{COD}\left(\mathrm{mgO}_{2} \mathrm{~L}^{-1}\right)$ & 8920 & 2246 & 357 & - \\
\hline $\mathrm{DBO}_{5}\left(\mathrm{mgO}_{2} \mathrm{~L}^{-1}\right)$ & 1895.4 & 786.41 & 220 & 400 \\
\hline $\mathrm{DBO}_{5} / \mathrm{DCO}$ & 0.22 & 0.27 & 0.55 & \\
\hline Absorbance (at $460 \mathrm{~nm}$ ) & 1.168 & 0.053 & 0.023 & - \\
\hline $\operatorname{TSS}\left(\mathrm{mg} \mathrm{L}^{-1}\right)$ & - & 1915 & 87 & \\
\hline $\operatorname{TDS}\left(\mathrm{mg} \mathrm{L} \mathrm{L}^{-1}\right)$ & - & 28150 & 920 & \\
\hline Soluble COD/total COD & 0.98 & 0.77 & 0.89 & \\
\hline$\%$ Total COD removal & 44 & 82 & 98 & \\
\hline$\%$ Total BOD removal & 22 & 67 & 91 & \\
\hline
\end{tabular}

\subsection{Identification of organic compounds in leachates}

The compounds present in the leachate samples, whose spectra signal quality was greater than $98 \%$, were separated and identified by GC-MS. As an example, Figure 2 shows the chromatograms obtained for leachate sample 2. 


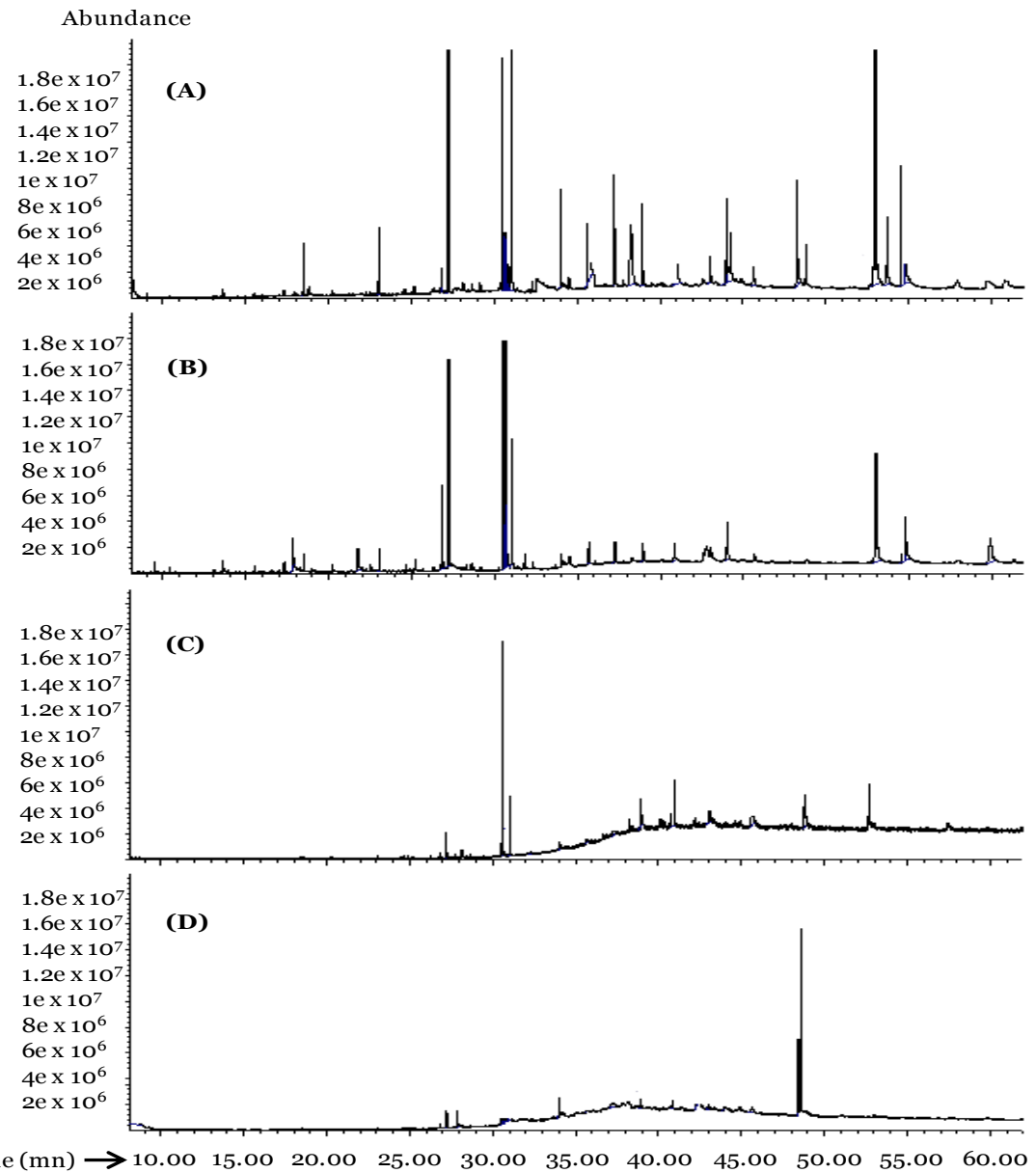

Figure 2. Chromatograms of Raw leachates (A), leachates after coagulation-flocculation (B), leachates after fenton

It is observed that the chromatograms of $\mathrm{RL}, \mathrm{TL}_{\mathrm{CF}}$ and $\mathrm{TL}_{\mathrm{F}}$ have a large number of peaks corresponding to the organic compounds found. These represent a source of contamination and could be harmful to the urbanized streams and aquatic environment if discharged without the proper treatment. The adsorption effluent chromatogram exhibits a smaller number of peaks compared to chromatograms 2 (A), (B) and (C).

The semi-quantification and the removal of persistent compounds in each stage of the process in the RL are shown in Table 3.

Table 3. List of predominant compounds in the raw leachates

\begin{tabular}{|c|c|c|c|c|c|}
\hline \multirow[t]{2}{*}{ No. } & \multirow[t]{2}{*}{ Compound } & \multicolumn{4}{|c|}{ Samples } \\
\hline & & 1 & 2 & 3 & 4 \\
\hline 1 & 1-2-diphenylcyclobutane & $\mathrm{x}$ & $\mathrm{x}$ & $\mathrm{x}$ & $\mathrm{x}$ \\
\hline 2 & 2- 4 Bisphenol & $\mathrm{x}$ & $\mathrm{x}$ & $\mathrm{x}$ & $\mathrm{x}$ \\
\hline 3 & 4 methyl phenol & & $\mathrm{x}$ & $\mathrm{x}$ & $\mathrm{x}$ \\
\hline 4 & Anthracene & $\mathrm{x}$ & $\mathrm{x}$ & & $\mathrm{x}$ \\
\hline 5 & Butylphtalate: DBP & $\mathrm{x}$ & $\mathrm{x}$ & $\mathrm{x}$ & $\mathrm{x}$ \\
\hline 6 & 4 phenyl cyclohexane & $\mathrm{x}$ & $\mathrm{x}$ & $\mathrm{x}$ & \\
\hline 7 & 1-2 benzenedicarboxylic acid & $\mathrm{x}$ & $\mathrm{x}$ & $\mathrm{x}$ & \\
\hline 8 & Bis (2-methoxyethyl) ester: DMEP & & $\mathrm{x}$ & $\mathrm{x}$ & $\mathrm{x}$ \\
\hline 9 & 2-Chlorocyclohexanol & $\mathrm{x}$ & & $\mathrm{x}$ & $\mathrm{x}$ \\
\hline 10 & Naphtalene & $\mathrm{x}$ & $\mathrm{x}$ & $\mathrm{x}$ & \\
\hline 11 & $\begin{array}{l}\text { Mono (2-ethylhexyl) ester 1,2-benzenedicarboxylic acid } \\
\text { cholestanol }\end{array}$ & & $\mathrm{x}$ & $\mathrm{x}$ & $\mathrm{x}$ \\
\hline 12 & & $\mathrm{x}$ & $\mathrm{x}$ & $\mathrm{x}$ & $\mathrm{x}$ \\
\hline
\end{tabular}

The total corrected area from the adsorption effluent in sample 2 decreased $99.93 \%$ compared to the total area of the RL; therefore, a high removal of organic compounds was observed after applying the combined treatment process. After adsorption, mono (2-ethylhexyl) ester 1,2-benzenedicarboxylic acid was found; its removal was $95.44 \%$. The compounds not found in the effluent were considered as completely removed. The 
average decrease in corrected areas of the raw leachate with respect to the adsorption effluent on the four samples was $98.2 \%$.

The persistent major components in the four samples in the raw leachate were 1,2-diphenylcyclobutane, 2-4 bis-phenol, butylphtalate and cholestanol with an average area of $12.07 \pm 6,20.42 \pm 8.2 \%, 0.54 \pm 0.3$ and $30.27 \pm 9.6 \%$, respectively. For the coagulation-flocculation, the major components found were 1,2diphenylcyclobutane and 2-4 bis-phenol with an average area of $13.1 \pm 6$ and $30.51 \pm 9.3$, respectively. For the Fenton-effluent, the major component found was $2-4$ bis-phenol with an average area of $27.5 \pm 11.5 \%$. For the adsorption effluent, the major component was mono (2-ethylhexyl) ester 1,2-benzenedicarboxylic acid with an average area of $33.6 \pm 16.2 \%$.

Twelve predominant compounds were identified in at least three out of four samples from the raw leachates. Among them, there were two phenolic compounds ( $\mathrm{N}^{\circ} 2$ and 3$)$, three aromatic acids $\left(\mathrm{N}^{\circ} 1,6\right.$, and 7$)$, one aliphatic acid and ester $\left(\mathrm{N}^{\circ} 8\right)$, two polyaromatic hydrocarbon $\left(\mathrm{PAH}_{\mathrm{S}}\right)\left(\mathrm{N}^{\circ} 4\right.$ and 10), one phthalate ester $\left(\mathrm{N}^{\circ} 5\right.$ and 11) and two alcohols $\left(\mathrm{N}^{\circ} 9\right.$ and 12). These compounds are shown in Table 4. All of them have carcinogenic and mutagenic properties [29].

Among the phenolic compounds found, 4-methyl-phenol is corrosive to the eyes, skin and respiratory tract; also, it is corrosive if ingested, can affect the central nervous system and several organs [30]. It has been previously been reported in wastewater, urban snow, runoff and landfill leachate [31-34].

Likewise, PAHs and phthalate ester were also found. The PAHs are emitted from combustion and petroleum sources whereas the phenols and phthalates are emitted mainly from consumer products and building materials $[35,36]$. As several of the selected PAHs, phenols and phthalates show acute toxic, carcinogenic and estrogenic effects on aquatic organisms, their occurrence in leachate and stormwater may pose a threat to receiving water quality [35-37].

Mono (2-ethylhexyl) ester 1,2-benzenedicarboxylic acid, which is a phthalate used in the manufacture of PVC and is regarded as a potential endocrine disruptor, was found as well $[38,39]$ conclude that the possible origin of this compound in the leachate is the disposition of paints, varnishes, plasticizers, pesticides, insecticides, repellents, disinfectants, motor oil, etc. 2-chlorocyclohexanol was found in three samples. It is persistent to coagulation-flocculation, Fenton oxidation and to adsorption with activated carbon.

Table 4. Comparison between areas of persistent compounds identified by GC-MS of sample 2

\begin{tabular}{|c|c|c|c|c|c|c|c|}
\hline \multirow[b]{2}{*}{ Compounds } & \multirow{2}{*}{$\begin{array}{l}\text { Raw leachates } \\
\text { Corrected area }\end{array}$} & \multicolumn{2}{|l|}{$\begin{array}{l}\text { Coagulation- } \\
\text { flocculation } \\
\text { effluent }\end{array}$} & \multirow[t]{2}{*}{$\begin{array}{l}\text { Fenton } \\
\text { effluent }\end{array}$} & \multicolumn{3}{|c|}{$\begin{array}{l}\text { Adsorption } \\
\text { effluent }\end{array}$} \\
\hline & & Corrected area & $\begin{array}{c}\% \\
\text { Removal }\end{array}$ & & $\begin{array}{c}\% \\
\text { Removal }\end{array}$ & $\begin{array}{c}\text { Corrected } \\
\text { area }\end{array}$ & $\begin{array}{c}\% \\
\text { Removal }\end{array}$ \\
\hline 2-4 Bisphenol & $16,937,447$ & $15,190,458$ & 10.31 & $13,203,342$ & 22.04 & - & 100 \\
\hline 4 methyl phenol & $12,106,823$ & $9,896,101$ & 18.26 & $4,372,518$ & 63.88 & - & 100 \\
\hline Anthracene & $15,847,133$ & $13,123,072$ & 17.18 & $6,911,021$ & 56.38 & - & 100 \\
\hline Butylphtalate: DBP & $21,094,318$ & $17,520,969$ & 16.93 & $7,203,007$ & 65.85 & - & 100 \\
\hline 4 phenyl cyclohexane & $19,154,821$ & $15,763,542$ & 17.70 & $4,921,233$ & 74.3 & - & 100 \\
\hline $\begin{array}{l}\text { Mono (2-ethylhexyl) ester 1,2- } \\
\text { benzenedicarboxylic acid }\end{array}$ & $19,198,395$ & $14,003,951$ & 27.05 & $3,815,274$ & 80.12 & 874,237 & 95.44 \\
\hline 2-Chlorocyclohexanol & $19,842,193$ & $16,000,873$ & 19.35 & 698,915 & 96.47 & - & 100 \\
\hline Cholestanol & $24,086,215$ & $23,101,002$ & 4.09 & $21,763,191$ & 9.64 & - & 100 \\
\hline Total corrected area & $9,925,198,944$ & $7,898,942,118$ & 20.41 & $3,289,732,982$ & 66.85 & $6,680,850$ & 99.93 \\
\hline
\end{tabular}

After the coagulation-flocculation process, all predominant compounds found in the raw leachate showed only a slow decrease. Urase and Miyashita [40] also found that a major fraction of organic matter in landfill leachates remained in the filtered samples.

The predominant compounds in the leachate found after the Fenton-filtration treatment in at least three out of four samples are listed as follows: 4-methyl-phenol; 2,4-bis-phenol; cholestanol and mono (2-ethylhexyl) ester 1,2-benzenedicarboxylic acid. This last compound was the only compound that remained in the leachate treated by the combined treatment but not show signs of high toxicity. This phthalate is highly hydrophobic and is expected to adsorb strongly to particles, hence can be removed by filtration and sedimentation. However, despite its hydrophobic character, mono (2-ethylhexyl) ester 1,2-benzenedicarboxylic acid was detected in the dissolved treated samples (Fig. 2). This indicates that the partition coefficient to the particulate organic content $\mathrm{K}_{\mathrm{OC}}$ in the water samples of mono (2-ethylhexyl) ester 1,2-benzenedicarboxylic acid is decreased by components of the sample matrix, for example DOC as suggested by Lee and Kuo [41].

\subsection{Toxicity reduction}

The RL showed a toxic effect, since the raw effluent completely inhibited the germination of tomato (Lycopersicon. esculentum) (Fig. 3). The toxicity unit (TU) of RL was 20.51. The Phytotoxicity could be

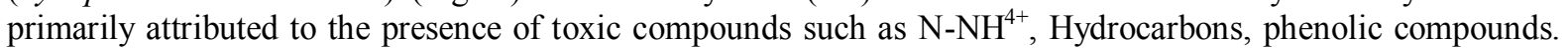


The combined physic-chemicals treatment process was very efficient. Therefore, the treated effluent reached over $90 \%$ removal of toxicity [28].

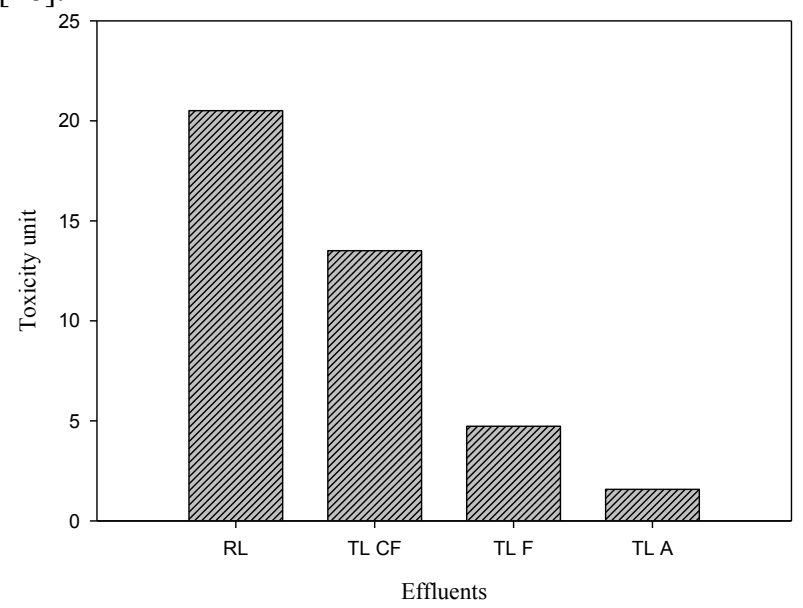

RL: Raw leachates; $\mathrm{TL}_{\mathrm{CF}}$ : leachates treated by coagulation flocculation; $\mathrm{TL}_{\mathrm{F}}$ : leachates treated by Fenton; $\mathrm{TL}_{\mathrm{A}}$ : leachates treated by adsorption

Figure. 3 toxicity along different treatment process

\section{Conclusion}

Phenolic compounds, aromatic acids, aliphatic acid and ester, $\mathrm{PAH}_{\mathrm{S}}$, phthalate ester and alcohols were detected in the raw and most of the treated leachates. Among these, 4-methyl-phenol and 2,4-bis-phenol have toxic properties.

Mono (2-ethylhexyl) ester 1,2-benzenedicarboxylic acid was the only compound that remained in the leachate treated by the coagulation-flocculation and Fenton-Adsorption process. It not shows signs of high toxicity.

The effluent obtained from the aforementioned treatment of leachates from the landfill of Bizerte city presented parameters within the maximum limits allowed by the existing legislative guidelines for the discharge of treated wastewaters in the public Tunisian canalizations [42]. In consequence, they may be safely discharged into urbanized streams without potential environmental risk $\left(\mathrm{COD}=398 \mathrm{mg} \mathrm{L}^{-1}\right.$ and $\left.\mathrm{BOD}_{5}=220 \mathrm{mg} \mathrm{L}^{-1}\right)$ The $\mathrm{COD}$ and $\mathrm{BOD}_{5}$ removal percentages achieved were greater than $91 \%$ in the treated leachate.

There was a decrease greater than $99 \%$ in the total corrected area from the chromatograms of the adsorption effluent compared to the raw leachate chromatograms. Therefore, the reduction of organic matter was high.

The proposed treatment, in addition to be effective for methanogenic leachate treatment, has lower phytoxicity expressed as toxicity units of tomato (Lycopersicon. esculentum). Under these considerations, the treated effluent can be discharged in the urbanized stream.

\section{References}

[1] ANPE (2001). National Agency of Protection of the Environment, supervision of the national programme of solid wastes gestion (PRONAGDES).

[2] A.L. Reitzel and A. ledin, Determination of phenols in landfill leachates contaminated groundwaters by solid phase extraction, Journal of Chromatography A, 972, 2002, 175-182.

[3] S. Marttinen, R. Kettunen and J Rintalla, Occurrence and removal of organic pollutants in sewages and landfill leachates, Sci Total Environ, 301, 2003, 1-12.

[4] H. Zhang, X. Wu and X. Li, Oxidation and coagulation removal of COD from landfill leachate by fered- Fenton process, Chemical Engeneering Journal, 2012, 188-194.

[5] R. Mejberi, G. Matejka, P. Lafrance and M Mazet, Fractionation and characterization of the organic matter in sanitary landfill leachates. Revue des sciences de l'eau, 1995, 217-236.

[6] S. Renou, S. Poulain, J.G. Givaudan and P. Moulin, Treatment process adapted to stabilized leachates: lime precipitationprefiltration-reverse osmosis, J Hazard Mater, 313, 2008, 9-22.

[7] S. Wang, X. Wu, Y. Wang, Q. Li and M Tao, Removal of organic matter and ammonia nitrogen from landfill leachate by ultrasound, Ultrason. Sonochemical, 15, 2008 933-937.

[8] K, Okawa, K. Suzuki, T. Takeshita and K. Nakanoa, Degradation of chemical substances using wet peroxide oxidation under mild conditions, Journal of Hazardous Materials, 127, 2005, 68- 72.

[9] T. A. Kurniawan, W.H. Lo and G.Y. Chan, Physico-chemical treatments for removal of recalcitrant contaminants from landfill leachate, Journal of Hazardous Materials, 129, 2006, 80-100.

[10] S. Cortez, P. Teixeira, R. Oliveira and M. Mota, Evaluation of Fenton and ozone-based advanced oxidation processes as mature landfill leachate pre-treatments, Journal of Environmental Management, 92, 2011, 749-755.

[11] Y. Deng, Iron-Mediated Physico-Oxidative Treatment of High Strength Recalcitrant Organic Wastewater: Landfill Leachate, dissertation, University of Miami, 2006. 
[12] S. Mohajeri, H. Abdul, M. Ali, L. Mohajeri, M. Bashir, S. Qarani, M. Nordin and M. Hasnain, Multiple responses analysis and modeling of Fenton process for treatment of high strength landfill leachate, Water Science Technology, 64 (8), 2011, 1652-1660.

[13] W. Moravia, L. Lange and M. Amaral, Evaluation of microfiltration for removal of sludge generated in advanced oxidation process by reagent in treatment of landfill leachate, Engenharia Sanitaria Ambiental, 16 (4), 2011, 379-386.

[14] R.I. Mendez, E.R. Castillo, M.R. Sauri, C.A. Quintal, G. Giacoman and B. Jimenez, Comparacion de cuatro tratamientos fisicoquimicos de lixiviados, Revista Internaaonal de Contaminacion Ambieental, 25 (3), 2009, 133-145(in Italie).

[15] W. Li, T. Hua, Q. Zhou, S. Zhang and F. Li, Treatment of stabilized landfill leachate by the combined process of coagulation/flocculation and powder activated carbon adsorption, Desalination, 264 (2), 2010, 56-62.

[16] G. C. Pillay, Etude des propriétés des mâchefers d'incinération d'ordures ménagères. Application à l'épuration des lixiviats de décharges, Thèse de doctorat, Institut National des sciences Appliquées de Lyon. IDO 8505, 1985.

[17] F. Kargi and Y. Pamukoglu, Powered activated carbon added biological treatment of pre-treated landfill leachate in a fed-batch reactor, Biotechnology Letters, 25, 2003, 695-699.

[18] A. N. Angelakis, M. H. Marecos Do Monte, L. Bontoux and T. Asano, The status of wastewater reuse practice in the mediterranean basin: need for guidelines, Water Research, 33, 1999, 2201-2217.

[19] AFNOR, Protocole d'evaluation d'une methode alternative d'analyse physico-chimique par rapport a une methode de reference [Protocol evaluation of an alternative physico-chemical methode analysis report to a referring methode], Norme NF XPT [Standard NF XPT], 58, 1999, 90-210

[20] R.J. Knetchel, A more economical method for the determination of chemical oxygen demand, Water Pollution Control, 71, 1978, 25-29.

[21] J.S.A, Japanese Standards Association, JIS handbook, in: Y. Ohama (Ed.), Environmental Technology, Tokyo, 1995, 553-638.

[22] A. F. Navarro, J. Cegarra, A. Roig and D. Garcia, Relationships between organic matter and carbon contents of organic wastes. Bioresource Technology, 44, 1993, 203-207.

[23] Y.M. Sang, Q.B. Gu, T.C. Sun and F.S. Li, Color and organic compounds removal from secondary effluent of landfill leachate with a novel inorganic polymer coagulant, Water Science Technology, 58, 2008, 1423-1432.

[24] F. Zucconi, A. Pera, M. Forte and M. De Bertoldi, Evaluating toxicity of immature compost, BioCycle, 22, 1981, 54-57.

[25] L.A. Kapustka, Selection of Phytotoxicity tests for use in ecological risk assessements.In: Wang, W., Gorsuch, j.W., Hughes, J.S. (Eds.), Plants for environmental studies. CRC press, BOCA Raton, 1997, 515-548.

[26] P. Brain and R. Cousens, An equation to describe doses responses where there is stimulation of growth at low dose, Weed research 29, 1989, 93-96.

[27] D. R. Ramirez-Sosa, E.R. Castillo-Borges, R.I. Mendez-Novelo, M.R. Sauri-Riancho, M. Barcelo-Quintal, and J.M. MarrufoGomez, Determination of organic compounds in landfill leachates treated by Fenton-Adsorption, Waste Management, 33, 2013, 390-395.

[28] N. Turki, K. Elghniji, D. Belhadj and J. Bouzid, Efficiency of an Integrated Process in Reduction of the Organic Loads in Methanogenic Landfill Leachates, European Journal of Scientific Research, 110, 2013, 556 - 568.

[29] M. Castillo and D. Barcelo, Characterisation of organic pollutants in textile wastewaters and landfill leachate by using toxicitybased fractionation methods followed by liquid and gas chromatography coupled to mass spectrometric detection, Anal ytic Chimical Acta, 426, 2001, 253-264.

[30] CDC, Centers for Disease Control and Prevention. International Chemical Safety Cards (ICSCs), $<$ http://www.cdc.gov/niosh/ipcs/icstart.html > (May 27, 2011).

[31] A. Baun, A. Ledin, L.A. Reitzel, P.L. Bjerg and T.H. Christensen, Xenobiotic organic compounds in leachates from ten Danish MSW landfills—chemical analysis and toxicity tests, Water Research, 38, 2004, 3845-3858.

[32] R.J. Slack, J.R. Gronow and N. Voulvoulis, Household hazardous waste in municipal landfills: contaminants in leachate, Science of Total Environment, 337, 2005, 119-137.

[33] K. Björklund, A. Palm Cousins, A.M. Strömvall, and P.A. Malmqvist, Phthalates and nonylphenols in urban runoff: occurrence, distribution and area emission factors, Science of the Total Environment, 407, 2009, 4665-4672.

[34] J. Sànchez-Avila, J. Bonet, G. Velascoand S. Lacorte, Determination and occurrence of phthalates, alkylphenols, bisphenol A, PBDEs, PCBs and PAHs in an industrial sewage grid discharging to a municipal wastewater treatment plant, Science of the Total Environment, 407, 2009, 4157-4167.

[35] A.H. Neilson, PAHs and Related Compounds, The Handbook of Environmental Chemistry. Springer Verlag, Berlin/Heidelberg, Germany, 1998.

[36] M.R. Servos, Review of the aquatic toxicity, estrogenic responses and bioaccumulation of alkylphenols and alkylphenol polyethoxylates, Water Quality Research Journal of Canada, 34, 1999, 123-177.

[37] C. A. Staples, W.J. Adams, T.F. Parkerton, J.W. Gorsuch, G.R. Biddinger and K.H. Reinert, Aquatic toxicity of eighteen phthalate esters, Environmental Toxicology and Chemistry, 16, 1997, 875-891.

[38] ECB, Updated risk assessment report: 4,40-isopropylidenediphenol (bisphenol-A). In: European Chemicals Bureau (Ed.), European Union Risk Assessment Report. Office for Official Publications of the European Communities, Luxembourg, 2010, 695.

[39] P.J. He, Z. Zheng, H. Zhang, L.M. Shao and Q.Y. Tang, Phthalic acid esters and bisphenol: a removal in landfill leachate with Fenton process and its relationship with leachate dissolved organic matter composition, Science of the Total Environment, 407, 2009, 4928-4933.

[40] T. Urase and K. Miyashita, Factors affecting the concentration of bisphenol A in leachates from solid waste disposal sites and its fate in treatment processes, Journal of Material Cycles and Waste Management, 5, 2003, 77-82.

[41] C. L. Lee and L.J. Kuo, Quantification of the dissolved organic matter effect on the sorption of hydrophobic organic pollutant: application of an overall mechanistic sorption model, Chemosphere, 38, 1999, 807-821.

[42] Norme Tunisienne NT. 106.002, Relative aux rejets d'effluents dans le milieu hydrique (Protection de l'environnement), 1989. 